\title{
SOCIAL CAPITAL AND QUALITY OF EDUCATION IN FAJAR UNIVERSITY MAKASSAR
}

\author{
SRI ADRIANTI MUIN \\ Fajar University Makassar \\ sriandriantim25@gmail.com \\ Paper ID : 28-1-2-20180326
}

\begin{abstract}
This study aims to determine social capital in quality of education at Fajar University Makassar. This research uses descriptive qualitative method, with research subject that is element of leadership, lecturer, staff and student. Sampling technique is purposive sampling method. Technique of collecting data by observation, interview and documentation. Data analysis by reducing data, presenting data and drawing conclusions. Test data validity using source and method triangulation. The elements of social capital studied are 1) the network consists of a solid relationship, cooperation and the use of social media as a means of liaison. 2) beliefs consisting of honesty, openness, and public interest, 3 ) institutions ie religious values, discipline, neatness and lecture contracts
\end{abstract}

Keywords: social capital, network, trust and institutions

\section{INTRODUCTION}

One of the characteristics of globalization is free competition which is characterized by the progress and rapid development of information technology. On the one hand, this progress is certainly a challenge for the world of education, but on the other hand, the advancement of information technology will be a threat, if the existing conditions can not anticipate the rapid progress of this.

Empirical facts have stated that one of the problems in the world of education in Indonesia, especially higher education is the quality / quality of education. Nasir (2015) argued that the quality of education and competitiveness of university graduates in Indonesia is still very low, both at the international level and among ASEAN countries. The same thing is stated by Rorim
(2014) that universities in Indonesia have low ability in running cooperation in global context and lack of competitiveness. Therefore, affirmed by Rais (2007) that the improvement of human resources is a necessity that must be done in a planned, directed, intensive, effective and efficient in the process of education development. Associated with the strategy of improving quality graduates can be done with a strategy to change one of the subsystems: human, structures, technology and organizational processes that include students who are educated, lecturers as educators and teachers, as well as facilities and infrastructure (Asmawi: 2004) will be able to increase the economic growth of a State (Atmanti and Hastarini: 2005).

DOI : 10.3828/IJEMSS/v1i1.6

VOLUME 1 ISSUE 1 MARCH 2018

http://journals..salewangang.org/ojs/index.php/IJEMSS/index

Licensed Under Creative Commons Attribution 4.0 
Rais (2007) found that human capital and financial capital alone was not enough to improve the quality. There is still one potential that has not been managed properly, namely social capital. Management of social capital as an educational development strategy encompassing networks, beliefs and norms can improve human capacity in addressing social problems in society (Syahra: 2003; Bueno (2002).

The National Education System Law No. 20 of 2003 says that the goal of national education is basically to create quality human resources, which can be achieved through quality education. Azzuhri 2009) that education as an integral part of the nation's development process should be built on an educational paradigm that has four pillars: education for all citizens, democratic education, education based on local culture, balanced education between faith-technology and sciencetechnology . Quality or quality itself is a direct characteristic of a product such as performance, reliability, easy of use and esthetics (Vincent Gaspers, 2005; Mukhid: 2007). Meanwhile, Priyono (2015) implements the criteria of university quality assessment covering human resources, management, student activities as well as research and publications and quality gaps between public and private universities occur in all criteria. Based on the criteria of quality education above, the object of this study is the element of leadership, lecturers, administrative staff, and students at the University of Fajar

The concept of social capital was first proposed by Judy Judson Hanifan (1916) to the pattern of mutual relationships within a society unit based on the principle of common virtue, sympathy and empathy. It is this concept that underlies various studies in social capital such as Putnam (1997); Adrianti (2013), which emphasizes on the public perspective, that social capital is a public good that is built by a society that comes from norms and beliefs as a basis in establishing cooperation and joint activities to achieve benefits. Bourdieu (1986); Bueou et al (2004); Syamsuddin (2003); Fatmawati (2004); Vermaak, Jaco (2009); Bjornskov, Christian and Sonderskov, Kim Mannemar (2013); Cvetanovic et al (2015); Mahmood, K (2015) argues that social capital is all of the actual and potential resources that a person possesses because of a network in a well-maintained relationship, as intangible assets that do not appear physically but are potent as innovation power will increase human capabilities overcome social problems in society.

\section{MATERIAL AND METHOD}

The method used in this research is qualitative descriptive. Data collection technique is purposive sampling. Sample consisted of university leaders, lecturers, staff and students. The data collection instrument uses interviews, sound and picture recording equipment. Data is analyzed at the time of data collection and after data collection is completed certain period. Data analysis techniques performed with reduction, display data and conclusion.

\section{RESULT AND DISCUSSION}

\section{Trust}

a. The element of belief in social capital is a very important element because it is a

DOI : $10.3828 / \mathrm{IJEMSS} / \mathrm{v} 1 \mathrm{i1} .6$

VOLUME 1 ISSUE 1 MARCH 2018

http://journals..salewangang.org/ojs/index.php/IJEMSS/index

Licensed Under Creative Commons Attribution 4.0 
basis in establishing a more complex relationship and cooperation (John Field: 2011). Similarly Fukuyama (2005), that social capital is the ability that arises from the existence of trust among its members in a community and is a very important factor in social capital in an institution. To cultivate this belief, the regularity, honesty and cooperative attitude is a behavior that is expected to foster trust. According to Nasyirah as Staff at Fajar University that honesty is a very important thing because it becomes the basis in establishing a relationship (interview dated August 31, 2016). The meaning of honesty is also expressed as a behavior in accordance with the rules outlined or in accordance with the norms that apply in general. This means that honesty is also related to how to work in accordance with established standards, with honesty also involves consistency and commitment in work (interview with Dr. Mulyadi Hamid, SE., M. Si, Deputy Rector I UNIFA, dated August 9, 2016). while for the students the meaning of honesty is the transparency of lecturers in conducting the assessment by correcting and returning the exam results and assignments given to the students concerned so that it can be a motivation to correct the mistake (Dewi, students of UNIFA, interview dated August 24, 2016)

b. Disclosure. In addition to the honesty factors that can foster trust is the attitude of disclosure or mutual acceptance of mutual help among members. In this case both students, lecturers, staff and leadership elements are open to each other in running activities within the Fajar University. The cooperative attitude is as demonstrated by the results of interviews with (Syamsul, student of UNIFA, interview August 24, 2016) or attitude as parents to their children (Asrul asmar, student of UNIFA, interview August 31, 2016). According to Abdul Majid Bakri, interview dated August 9, 2016 that the disclosure interpreted is the relationship between lecturers and students that have been well established, but between a program study with other courses, still need to be improved again so that the common goal can be achieved, so the quality will be more good. Disclosure is also interpreted by the leadership of Fajar University by continuing to socialize the standard operating procedures (SOP), because the SOP will be a reference and also at the same time controlling the behavior of members in the organization. This is also in accordance with research by Hery Harjono Muljo et al (2014) that to realize good university governance, one of them by applying standardized testing. Even the Leaders of Fajar University Dr. Mulyadi Hamid, deputy rector 1 UNIFA suggests that the management effort of Fajar University in disseminating SOP is nothing but to improve the quality. Especially SOP related teaching and learning activities.

c. The public interest. Trust is also associated with the public interest,

DOI : 10.3828/IJEMSS/v1i1.6

VOLUME 1 ISSUE 1 MARCH 2018

http://journals..salewangang.org/ojs/index.php/IJEMSS/index

Licensed Under Creative Commons Attribution 4.0 
which is characterized by the increasing number of students from year to year. As the results of research Chandra Hakim, et al (2014) that consumer confidence in a product affects his decision to buy the product. The results of interviews with the elements of leadership, staff, lecturers, and students responded that the public's trust in the existence of Fajar University is also getting better. The cause of the public interest is increasing due to the strategic location and easy reach as an interview conducted by UNIFA student Grace on the 24th August, as well as adequate facilities and infrastructure for the academic community for the smoothness of the educational process so that the quality of education can be as expected (interview with Syamsul, student of UNIFA dated August 24, 2016). While the public interest increased based on interviews with Abdul Madjid Bakri, dated August 24, 2016, also due to the fact that alumni can compete in the job market

\section{Social Networking}

a. Participation. Participation in a network is a form of involvement of all elements of academic society in various activities including in decision making, so as to create synergy in a working relationship as proposed by Abdul Majid Bakri, Lecturer, at the interview date August 24, 2016. Meaning Participation is reviewed further by the secretary of Faculty of Economics and Social Sciences, Usman Rendra, student of UNIFA, interview result dated
September 9, 2016) that externally participation is to carry out social service as a form of university awareness to society and environment while from internal aspect is routinely held meeting to hear suggestion and opinions, so that decisions can be made in a participatory manner. While for student participation is to follow extracurricular activity or student organization at University of Fajar. Student activities will be able to increase communication skills as stated by Muh. Asrul Asmar, a UNIFA student (interview dated August 26, 2016). Increase the ability to interact (Syamsul student of UNIFA, interview dated August 26, 2016), and add experience to better future (Jelly, UNIFA student, interview date August 24, 2016

b. Cooperation. Fukuyama (2005) points out the importance of effective teamwork in an organization. Cooperation supported by high trust will reduce organizational costs. Therefore, cooperation within the scope of Fajar University is no less important for the achievement of the quality of education, especially if supported by a high sense of trust so that a wider relationship can be achieved. Since its establishment until now, Fajar University has been doing a lot of cooperation with stake holders which give benefit to the development of Fajar University. As the result of interview with Dr. Mulyadi Hamid, deputy rector 1 on August 09, 2016, that cooperation allows the development of human resources both sides. This is where social capital is

DOI : 10.3828/IJEMSS/v1i1.6

VOLUME 1 ISSUE 1 MARCH 2018

http://journals..salewangang.org/ojs/index.php/IJEMSS/index

Licensed Under Creative Commons Attribution 4.0 
built, at the time of cooperation perceived benefits by all parties, with trust as adhesive, organizational goals can be more easily achieved. In addition to the development of human resources cooperation can also develop the organization, as stated by Muliana one of the lecturers in the interview dated August 24, 2016. While for the cooperation students can be very useful associated with the ease of students accepted work and jumped in the middle of society (Syamsul, interview dated 26 august 2016)

c. Social media. Today's information and communication technology plays an important role both in education, economics, social, geography, religion and other fields (Purwo Riwadi, without years). Furthermore Rudi Setiawan (2013) suggests that one facility for individuals or the internet community in socializing online can be done through online social media. In the environment of Fajar University, social media is a means of communicating among the academic community. Based on the results of interviews with informants, it was revealed that the Fajar University web site provides benefits for students to get the required information, such as scholarship information, as stated by a staff Nasyirah at the interview on August 31, 2016. Although other social media is considered more often used like Whatsapp and line, as the result of interview with a lecturer, Abdul Majid Bakri, on August 09, 2016. Another benefit of social media as a means of communication in building social networks is also felt by students with the availability of online study card plan, including student enrollment new. (Dr. Mulyadi Hamid, Deputy Rector I, interview dated August 9, 2016)

3. Institutions

Ahmad Imran Rozuli (without Year) suggests that sociologically, the dimensions of institutions can be traced through instutional arrangements that live and thrive in our society. This pattern has shaped the relational between formal (written) and informal (unwritten) rules. social capital becomes a frame that reinforces the pattern and institutional system to survive. According to Lubis (2001) social institutions are an important element of social capital apart from trust and social networking. Institutions consist of shared values, norms and sanctions, and rules

a. Religious Value as an institution can be the basic rule of moral value in society. It can therefore make a person respect each other, trust each other and build a discipline, honesty and social sensitivity, as well as a controller for having understood that if he commits an offense or negligence will get a sanction or punishment for his negligence. Abdul Majid Bakri, lecturer, interviewed on August 09, 2016, the leadership elements and student, that religious values can be a kind of cultural value of religious rituals that are believed and reflected in their social life behavior. While Nasyirah argued that religious values are used daily in carrying out activities, such as honesty.

DOI : 10.3828/IJEMSS/v1i1.6

VOLUME 1 ISSUE 1 MARCH 2018

http://journals..salewangang.org/ojs/index.php/IJEMSS/index

Licensed Under Creative Commons Attribution 4.0 
b. Discipline is an attitude to obey the rules and norms that apply in a group or organization. Pranata (2014) in I Gede Winarta, et al (2016) that the discipline of work is the attitude of obedience and employee loyalty to the written / unwritten rules are reflected in the form of behavior and actions on the company to achieve a certain goal. significant between discipline attitudes and achievement of goals. Nur Atifah (2006) also found that there is a correlation between disciplinary attitudes and improved learning achievement. Based on the results of interviews with the elements of leadership, staff and students said that Fajar University in carrying out activities to apply discipline as a way to achieve goals in quality of education. Discipline includes in terms of time, discipline in work, discipline in achievement of performance as proposed by Abdul Majid Bakri a lecturer, interview date of August 09, 2016. Discipline will also ensure the plans made will achieve the goal

c. Neatness. Haryanti Eko Nurwati (2010) states that the school environment that provides comfort, cleanliness, tidiness and beauty have a positive impact on the learning process is the improvement of learning achievement. Therefore Neatness also become a norm agreed by the University of Fajar in carrying out its activities. The standard tidiness of dressed at Fajar University is dressed politely, not wearing t-shirts and torn pants and not using sandals. Results of interviews with students of UNIFA,
Grace on August 24, 2016 suggested that tidiness can provide comfort in learning. While other students of UNIFA Syamsul, interview dated August 24, 2016 suggested that tidiness associated with behavior-related judgments. Based on the results of these interviews it is clear that tidiness is a reflection of effective communication in interacting and become institutions that contain values held by all academic community.

d. Lecture Contract. The course contract is basically a lecture design agreed by students and lecturers (Suciati 1997 in Elyusra 2011). Based on the results of interviews with the elements of leadership, lecturers, staff and students said that the application of lecture contracts at the university Fajar is mandatory. Lecturers are required to make lecture contracts at the beginning of the meeting that must be agreed with the students. The contracts list of assessment criteria, learning plan, orderly hours of delay, orderliness and tidiness and methods of learning management for one semester. Students also want a persuasive approach to apply the lecture contract more effectively (interview with Grace Student 5th semester on August 24, 2016) In addition the lecture contract should be flexible, such as the schedule that coincides with the national holiday (interview with Abdul Majid Bakri, August 9, 2016). The weakness in this qualitative research is that social capital and quality of education are not explicitly stated, but the results of

DOI : $10.3828 /$ IJEMSS/v1i1.6

VOLUME 1 ISSUE 1 MARCH 2018

http://journals..salewangang.org/ojs/index.php/IJEMSS/index

Licensed Under Creative Commons Attribution 4.0 
interviews with a number of competent informants gave the result that social capital related to the trust that can be seen from honesty, openness and public interest is a glue or that reinforces the Neatness at Fajar University which consists of religious values, discipline, neatness and contracts of lectures. While the trust built among the academic community of Fajar University has been able to build a social network consisting of participation, cooperation and the use of social media for a better learning process.

\section{CONCLUSION}

Based on the results of the discussion, then the conclusions that can be taken in this study are:

1. The social capital associated with the trust that can be seen from the honesty, openness and public interest is a glue or that reinforces the institution at Fajar University which consists of religious values, discipline, neatness and contracts of lectures.

2. The established trust among the academic community of Fajar University has been able to build a social network consisting of participation, cooperation and use of social media for better learning process.

\section{REFERENCE}

Abd. Mukhid. 2007. Improving the Quality of Education through the Right Learning System. Tadris. Volume 2 Number. pp 120-133
Ahmad Imron Rozuli, (without years). Diversity of Religious and Cultural Institutions and Its Implications for Strengthening the Economic Activity of Villages

Asy'ari Hasan.2009. Implementation of Corporate Social Responsibility (CSR) as Social Capital at PT. Newmont. Thesis of PPS Diponegoro University. Semarang

Bourdieu, P 1986 The Forms Of Capital. In J. Richardson (Ed) Handbook Of Theory and Research For The Sociology Of education. New York, Greenwood

Bueno, E, 2004. The Role of Social in Today's Economy. Empirical Evidence and Proposals of a New Model of Intellectual Capital. Journal of Intellectual Capital 5 (4): 556-574

Bjornskov, Christian, Sonderskov, Kim Mannemar. 2013. Is Social Capital a Good Concept.Social Indicators research. Volume 114, Issue 3. P 1225-1242

Candra Hakim, Ari Prasetya, Srikandi Kumadji, Edy Yulianto. 2014. Influence Brand Image, Product Quality Against Trust And Purchase Decision (Survey on Buyer of Honda Vario Motor at PT Sumber Purnama Sakti in Gresik Regency). Journal of Business Administration (JAB). Volume 15 No. 2 University of Brawijaya. Malang

DOI : 10.3828/IJEMSS/v1i1.6

VOLUME 1 ISSUE 1 MARCH 2018

http://journals..salewangang.org/ojs/index.php/IJEMSS/index

Licensed Under Creative Commons Attribution 4.0 
Cvetanovic, Slobodan, Despotovic, Danijela, Filipovic, Miloard, 2015 The concept of Social Capital in Economic Theory. Journal of Economics Volume 61, issue $1,73-84$

Dwi Atmanti, Hastarini. 2005 Human Resource Investment Through Education. Journal of Development Dynamics Volume 2 No. 1. Pp 30-39

Edy Priyono. 2016. The Quality of Our College. http://ristekdikti.go.id

Elyusra. 2011. Innovation, Motivating and Islamic Lectures contract http://adabundaguru.wordpress.com

Emzir.2014. Kualitatif Research Methods Data analysis. Rajawali Press. Jakarta

Francis Fukuyama. 2005. The Great Shock of Human Nature and New Social Order. Gramedia Pustaka Utama. Jakarta

Fatmawati Widyasari. 2104. Social Capital In Quality Education In Muhammadiyah Mutihan elementary school. S1. Thesis UNY

Hery Harjono Muljo et al. 2014. Optimizing the Implementation of Good Governance Principles of Academic Sector in Effort to Achieve Good University Governance. Binus Journal Volume 5 Number 1.

Gareth R. Jones.2001 Organizational Theory, Design and Change: Text and Cases 4th International Edition. Pearson Education Inc. New Jersey

Haryanti Eko Nurwati. 2010. The Influence of Environment Class and Student Learning Independence Against Achievement Learning Accounting Student Class XI IPS SMA Negeri 2 Karanganyar. Skripsi. Accounting Study Program. Faculty of Teacher Training and Education. muhammadiyah Surakarta university

Hasbullah J. 2006. Social Capital Towards the Excellence of Indonesian Human Culture. MR United Press. Jakarta

Hastarini Dwi Atmanti. 2005. Human Resource Investment Through Education. Economic Journal of Development Volume 2 number 1. Pp 35-39

I Gede Widiananta dkk.2016. Influence of Work Motivation and Work Discipline on Employee Achievement e-journal Bisma Ganesha University of Management Department. Volume 4

John Filed. 2011. Social Capital. Publisher: Creation Discourse. Yogyakarta.

Kartini Kartono. 1983. Leaders and leadership. Jakarta

Leanna C.M. 2010. Social Capital: The Collective Component of Teaching Quality. VUE Spring. Annenberg Institute For Scholl Reform

DOI : 10.3828/IJEMSS/v1i1.6

VOLUME 1 ISSUE 1 MARCH 2018

http://journals..salewangang.org/ojs/index.php/IJEMSS/index

Licensed Under Creative Commons Attribution 4.0 
Lubis, Zulkifli, B and Fikarwan Zuska. 2001. Resistance, Persistence and Models of Social Capital Transmission in the management of Common Property Resources. Research Report, Office of the Minister of State for Research and Technology of the Republic of Indonesia.

Mahmood, K. 2015. Social Capital From Concept To Theory. Pakistan of Science.Volume 67. Iss 1, 114-119

Merry Dita, Rahmatika. 2016. School Efforts in Increasing the Candidates of Students Candidates in Elementary School. Jogya Green School. S1. Thesis Universitas Negeri Yogyakarta

Muhammad Nasir, 2015. College graduates are still far behind. Speech in the National Symposium on Accounting XVII. Auditorium Universitas Sumatera Utara

Muhandi Azzuri. 2009. Quality Education (an effort to Realize Civil Society). Forum Tarbiyah. Volume 7 No. 2 pp. 143-156

Mohammad Fauzan. 2012. Improving Performance of Lecturer Based on Social Capital and Organizational Support in PTS Semarang City. Journal of Business and Economics (JBE). Volume 12. Number 2. Page. 188-202. ISSN: $1412-3126$

M. Rosul Asmawi. 2005. Strategy to Improve Quality Graduates in Higher Education.
Makara, Social Humanities, Volume 9, Number 2, pp 66-71

Muhammad Nasir, 2015. University graduates are still far behind. Speech in the National Symposium on Accounting XVII. Auditorium Univ. North Sumatra.

Nur Atifah. 2006. Relation of Discipline Level With Sociology Learning Achievement For IPS Grade Students States of Madrasah Aliyah Babakan Lebaksiu Tegal Lesson Year 2005 / 2006.Skripsi. Malang State University

Rahmat Rais. 2007. Social Capital As A Strategy Of Madrasah Development Studies At MAN I Surakarta. Ph.D Thesis. UIN Sunan Kalijaga Yogyakarta.

Rorim Panday.2014. University Quality Improvement Strategy for Strengthening Competitiveness Facing Southeast Asian Economic Community: A Case Study. Proceedings of SNEB.

Rusydi Syahra. 2003. Social Capital Concepts and Applications. Journal Society and Culture. Volume 5. Number 1. LIPI

Sjafri Mangkuprawira. 2010. Strategy of Capacity Building of Social Capital and Quality of Human Resources of Agricultural Development Companion. Agro-Economic Forum.

DOI : 10.3828/IJEMSS/v1i1.6

VOLUME 1 ISSUE 1 MARCH 2018

http://journals..salewangang.org/ojs/index.php/IJEMSS/index

Licensed Under Creative Commons Attribution 4.0 
Sri Adrianti Muin, 2013. Business Capacity Studies, Entrepreneurial Culture, Through Social Capital, and Entrepreneurship Attitudes on Small Business Performance in South Sulawesi. Journal of Development Economics Volume 2 No. 4 University of Haluoleo. 